\title{
DESKRIPSI PEMBERIAN PENGUATAN GURU TERHADAP MOTIVASI BELAJAR PADA SISWA KELAS V DI SDN 011 TARAKAN
}

\author{
Mutia Firdaus ${ }^{1}$, Muhammad Yunus ${ }^{2}$, Kadek Dewi Wahyuni Andari ${ }^{3}$ \\ ${ }^{123}$ Jurusan Pendidikan Guru Sekolah Dasar, Fakultas Keguruan dan IImu \\ Pendidikan Universitas Borneo Tarakan \\ 1'mutiafjr27@gmail.com, ²yunusabbas1965@gmail.com, \\ 3kadekdewi1985@gmail.com
}

\begin{abstract}
The purpose of this study is to describe the basic teaching skills of teachers in providing reinforcement to the fifth graders at SDN 011 Tarakan and to determine the benefits of skills to strengthen student motivation. This qualitative research was carried out at SDN 011 Tarakan in the 2018/2019 school year. This research focused on the basic teaching skills of the teachers in providing reinforcement and the benefits of skills in providing reinforcement to student motivation. Primary and secondary data were used as sources with the principal, teachers, school supervisors, and student as informants. Data were collected through observation, interviews, and documentation. The collected data were analyzed qualitatively through data reduction, data presentation, and conclusion drawing. The results showed that the teacher at SDN 011 Tarakan had applied basic teaching skills in providing reinforcement, such as verbal, psychomotor, signal,gestural,approaching, and activeness so that it was benefical to improve learning motivation of the fifth grade students.
\end{abstract}

Keywords: Strengthening Skills, Motivation, Qualitative

\begin{abstract}
ABSTRAK
Tujuan penelitian ini adalah untuk mendeskripsikan keterampilan dasar mengajar guru dalam memberi penguatan di kelas V SDN 011 Tarakan dan untuk mengetahui manfaat keterampilan memberi penguatan terhadap motivasi belajar siswa. Jenis penelitian ini menggunakan penelitian kualitatif yang dilaksanakan di SDN 011 Tarakan pada tahun ajaran 2018/2019. Penelitian ini berfokus pada keterampilan dasar mengajar guru dalam memberikan penguatan dan manfaat keterampilan memberi penguatan tehadap motivasi siswa. Adapun sumber data pada penelitian ini berupa data primer dan data sekunder dengan informan yaitu kepala sekolah, guru, pengawas sekolah dan siswa. Teknik pengumpulan data yang digunakan adalah wawancara, observasi dan dokumentasi. Serta menggunakan teknik analisis data kualitatif melalui reduksi data, penyajian data dan penarikan kesimpulan. Hasil penelitian menunjukkan bahwa guru di SDN 011 Tarakan telah menerapkan keterampilan dasar dalam memberikan penguatan, seperti penguatan verbal, penguatan sentuhan, penguatan tanda, penguatan gestural, penguatan mendekati, dan penguatan kegiatan sehingga bermanfaat pada motivasi belajar yang baik pada siswa kelas $\mathrm{V}$.
\end{abstract}

Kata Kunci: Keterampilan Memberikan Penguatan, motivasi, kualitatif 


\section{A. Pendahuluan}

Pendidikan adalah suatu proses yang bertujuan untuk mengubah sikap atau tingkah laku seseorang atau sekelompok orang sebagai upaya mendewasakan seseorang atau sekelompok orang baik melalui pengajaran maupun pelatihan. Berdasarkan pasal 1 ayat 1 Nomor 20 Tahun 2003 tentang Sistem Pendidikan Nasional, menyatakan bahwa pendidikan adalah usaha sadar dan terencana untuk mewujudkan suasana belajar dan proses pembelajaran agar peserta didik secara aktif mengembangkan potensi dirinya untuk memiliki kekuatan spiritual keagamaan, pengendalian diri, kepribadian, kecerdasan, akhlak mulia, serta keterampilan yang diperlukan dirinya, masyarakat, bangsa, dan Negara.

Jadi, dapat disimpulkan bahwa pendidikan merupakan suatu proses yang dilakukan secara sadar dan terencana dengan tujuan mengembangkan sikap atau tingkah laku, potensi diri, kecerdasan dan keterampilan seseorang atau sekelompok orang.Pendidikan di Indonesia terbagi menjadi tiga jalur, yaitu jalur pendidikan formal, jalur pendidikan non formal, dan jalur pendidikan informal. Jalur pendidikan formal terbagi menjadi beberapa jenjang, salah satunya adalah sekolah dasar. Berdasarkan pasal 17 ayat 1 Nomor 20 Tahun 2003 tentang Sistem Pendidikan Nasional, menyatakan bahwa pendidikan dasar merupakan jenjang pendidikan yang melandasi jenjang pendidikan menengah. Sekolah dasar adalah salah satu lembaga yang menjadi sumber pendidikan dasar dimana pengetahuan yang didapatkan oleh siswa akan digunakan untuk melanjutkan ke jenjang selanjutnya. Berdasarkan pernyataan tersebut, maka pengetahuan yang diperoleh siswa bisa berasal dari mana saja, salah satunya adalah pengetahuan yang bersumber dari guru yang berkualitas.

Peraturan Pemerintah Nomor 19 Tahun 2005 pasal 28 ayat 1 menyatakan bahwa pendidik harus memiliki kualitas akademik dan kompetensi sebagai agen pembelajaran, sehat jasmani dan rohani, serta memiliki kemampuan untuk mewujudkan pendidikan nasional. Selain guru diharuskan berkualitas, gurupun dituntut memiliki kompetensi. Sesuai dengan UndangUndang Nomor 14 tahun 2005 pasal 
10 ayat 1 tentang Guru dan Dosen, kompetensi yang dimaksud meliputi kompetensi pedagogik, kompetensi profesional, kompetensi sosial, dan kompetensi kepribadian.

Kompetensi

pedagogik

merupakan kemampuan guru yang secara langsung merancang suatu pembelajaran baik didalamnya terdapat implementasi, evaluasi, hingga pengembangan peserta didik. Mulyasa dalam Andini (2018:151) menyatakan bahwa kompetensi pedagogik secara langsung menyentuh kegiatan pembelajaran seperti perencanaan, perancangan, implementasi, hasil belajar, evaluasi, peserta didik dan pengembangan peserta didik yang kurang berprestasi sehingga menyebabkan kompetensi pedagogik menjadi salah satu penentu keberhasilan pembelajaran.

Kompetensi pedagogik ada kaitannya dengan keterampilan dasar guru dalam melakukan kegiatan pembelajaran. Kegiatan pembelajaran dikelas sebaiknya dilakukan oleh guru yang telah benar-benar menguasai materi yang akan disampaikan, selain itu dibutuhkan pula keterampilan dasar mengajar yang juga harus dikuasai oleh guru, sehingga guru menjadi fasilitator dalam penelitian ini.
Penguasaan keterampilan dasar mengajar oleh guru bertujuan agar pembelajaran menjadi efektif. Djamarah dalam Sabransyah (2017:3) menyatakan bahwa terdapat delapan keterampilan dasar mengajar yang harus dimiliki oleh guru, seperti keterampilan membuka dan menutup pembelajaran, keterampilan bertanya, keterampilan mengadakan variasi,keterampilan menjelaskan, keterampilan membimbing diskusi kelompok kecil, keterampilan mengelola kelas, keterampilan mengajar kelompok kecil dan perorangan, serta keterampilan memberi penguatan.

Apabila guru ingin pembelajaran berlangsung secara efektif, maka salah satu caranya adalah dengan menerapkan keterampilan dasar mengajar secara menyeluruh.Secara tidak langsung, keterampilan dasar mengajar juga dapat berpengaruh terhadap motivasi siswa. Oleh karena itu, apabila keterampilan dasar mengajar dilakukan secara nyata akan memengaruhi motivasi siswa sehingga tujuan pembelajaran lebih mudah dicapai.

Motivasi merupakan dorongan pada diri seseorang yang ditandai dengan munculnya tanggapan untuk 
melakukan sesuatu demi mencapai tujuan tertentu. Sardiman (2014:73) menyatakan bahwa motivasi adalah cara yang mendorong seseorang untuk melakukan sesuatu.

Namun, pada saat ini di sekolah tidak seluruh guru dapat menguasai dan menerapkan kedelapan keterampilan dasar mengajar tersebut dengan baik sehingga berdampak pada motivasi siswa saat kegiatan pembelajaran berlangsung.

Berdasarkan hasil observasi dan wawancara yang dilakukan dengan guru kelas V SDN 011 Tarakan, bahwa terdapat masalah yang berkaitan dengan keterampilan dasar mengajar guru. Keterampilan dasar mengajar yang belum dipahami dan dikuasai oleh guru, yaitu keterampilan dasar memberi penguatan.

Permasalahan tersebut terjadi karena kurangnya pemahaman guru terhadap keterampilan dasar memberi penguatan sehingga menyebabkan guru tidak sepenuhnya menerapkan keterampilan dasar mengajar tersebut, seperti guru belum melakukan penguatan kegiatan kepada siswa yaitu mengizinkan siswa untuk istirahat terlebih dahulu ketika siswa mampu menyelesaikan tugas atau berhasil melakukan sesuatu. Selain itu, guru juga belum melakukan penguatan mendekati, yaitu posisi guru tetap berada di depan kelas saja meskipun terdapat beberapa siswa yang tidak memerhatikannya saat pembelajaran berlangsung. Hal ini yang akhirnya berdampak pada siswa, dimana kurangnya perhatian siswa terhadap penjelasan guru sehingga menyebabkan suasana kelas menjadi tidak kondusif.

Jika guru dapat menerapkan keterampilan dasar penguatan dengan baik, maka dapat membantu meningkatkan motivasi siswa saat pembelajaran berlangsung. $\mathrm{Hal}$ ini diperkuat oleh penelitian sebelumnya yang dilakukan oleh Rosida (2015) yang berjudul "Pemberian Penguatan Pembelajaran Sebagai Upaya Meningkatkan Motivasi dan Prestasi Siswa Pada Pembelajaran Bahasa Indonesia". Adapun hasil penelitian tersebut adalah penerapan penguatan yang diterapkan oleh guru dapat meningkatkan motivasi siswa, merangsang siswa untuk berpikir kritis, meningkatkan perhatian siswa, mengembangkan kemampuan berinisiatif siswa, dan mengendalikan sikap siswa. Sehingga siswa lebih meningkatkan prestasinya. 
Berdasarkan uraian latar belakang tersebut, peneliti tertarik untuk melakukan penelitian mengenai penerapan keterampilan dasar memberi penguatan guru terhadap motivasi siswa yang berjudul "Deskripsi Keterampilan Dasar Guru Dalam Memberi Penguatan di Kelas V SDN 011 Tarakan".

\section{B. Metode Penelitian}

Penelitian yang digunakan merupakan penelitian kualitatif deskriptif. Menurut Moleong (2017:6) penelitian deskriptif adalah penelitian yang menggambarkan keadaan yang terjadi saat penelitian berjalan dan memaparkan data yang diperoleh.

Adapun instrumen penelitian pada penelitian ini adalah peneliti itu sendiri. Serta, adapun instrumen pendukung yang digunakan adalah lembar observasi, pedoman wawancara, dan studi dokumen.

Penelitian ini menggunakan teknik pengumpulan data. Teknik pengumpulan data merupakan suatu proses yang digunakan untuk memeroleh data untuk keperluan penelitian. Pada penelitian ini menggunakan teknik pengumpulan data berupa observasi, wawancara, dan dokumentasi.
Selain itu, penelitian ini juga menggunakanteknik analisis data. Dalam penelitian ini menggunakan model interaktif model Miles dan Huberman. Analisis data dimulai dari tahap reduksi data, penyajian data, dan penarikan kesimpulan.

\section{Hasil Penelitian Dan Pembahasan}

\section{Keterampilan Dasar Mengajar} Guru dalam Memberi Penguatan di SDN 011 Tarakan

\section{a. Penguatan Verbal}

Djamarah (2000: 102) yang menyatakan bahwa penguatan verbal adalah pemberian pujian maupun dorongan yang guru berikan untuk merespon tingkah laku yang telah dilakukan oleh siswa. Berdasarkan penjabaran hasil penelitian dan teori yang ada, dapat disimpulkan bahwa guru telah melakukan penguatan verbal, yaitu penguatan berupa katakata atau kalimat pujian atas tingkah laku yang telah dilakukan oleh siswa saat kegiatan pembelajaran. Adapun penguatan verbal yang guru berikan saat pembelajaran sedang berlangsung, yaitu seperti mengucapkan kata "pintar" dan "hebat". Selain itu, guru juga mengucapkan kalimat "wow hebat", dan "jawabanmu tepat sekali". 


\section{b. Penguatan Sentuhan}

Febianti (2018: 94) bahwa penguatan sentuhan (contact) yaitu penghargaan bagi siswa atas usaha yang dilakukan siswa dengan cara menepuk bahu atau menjabat tangan dengan siswa. Berdasarkan penjabaran teori yang ada, maka dapat disimpulkan bahwa guru telah melakukan penguatan sentuhan, dimana penguatan yang dilakukan oleh guru dengan cara menyentuh siswa secara fisik. Penguatan sentuhan yang guru lakukan seperti menepuk pundak dan berjabat tangan dengan siswa. Guru melakukan penguatan sentuhan dengan cara menepuk pundak siswa saat kegiatan pembelajaran sedang berlangsung. Selain itu, guru juga berjabat tangan dengan ssiwa ketika siswa akan keluar kelas saat jam istirahat.

\section{c. Penguatan Tanda}

Halimah (2017: 129) yang menyatakan bahwa guru dapat memberikan penguatan tanda berupa simbol atau benda yang sesuai dengan kegemaran siswa.

Berdasarkan penjabaran teori tersebut, dapat disimpulkan bahwa guru telah melakukan pemberian penguatan tanda, yaitu guru memberikan hadiah atau simbol sebagai

penguatan

terhada pencapaian yang telah diraih oleh siswa. Guru melakukan penguatan tanda dengan cara memberikan hadiah berupa benda (alat tulis) dan beasiswa ketika siswa berhasil memeroleh peringkat di kelas. Selain itu, penguatan tanda yang guru berikan kepada siswa adalah pemberian nilai pada tugas yang telah selesai dikerjakan oleh siswa.

\section{d. Penguatan Gestural}

Usman (2011: 81) yang menyatakan bahwa penguatan gestural yang dapat guru lakukan seperti memberikan acungan jempol, bertepuk tangan, senyuman dan gerakan lainnya sesuai kebutuhan guru. Berdasarkan beberapa teori tersebut, dapat disimpulkan bahwa guru telah melakukan penguatan gestural saat pembelajaran, yaitu penguatan berupa gerak tubuh yang guru berikan kepada siswa. Hal ini dilakukan guru dengan cara memberikan senyuman ketika siswa sedang mengerjakan tugas. Selain itu, guru juga tidak lupa memberikan acungan jempol dan mengajak siswa bertepuk tangan ketika siswa berhasil melakukan sesuatu. Adapun tepuk tangan khas yang dimiliki kelas yang 
peneliti teliti adalah tepuk tangan "wow hebat".

\section{e. Penguatan Kegiatan \\ Djamarah (2000: 102) yang} menyatakan bahwa penguatan dalam bentuk kegiatan ini banyak terjadi bila guru menggunakan suatu kegiatan atau tugas, sehingga siswa dapat memilihnya atau menikmatinya sebagai suatu hadiah atas suatu pekerjaan atau tingkah laku yang telah dilakukannya. Berdasarkan penjabaran teori tersebut, maka dapat disimpulkan bahwa guru telah melakukan penguatan kegiatan, dimana guru memberikan kegiatan yang menyenangkan bagi siswa saat pembelajaran sedang berlangsung. Guru memberikan penguatan kegiatan kepada siswa ketika siswa telah menyelesaikan tugas yang diberikan oleh guru. Ketika siswa telah menyelesaikan tugas yang diberikan oleh guru, maka siswa diizinkan istirahat terlebih dahulu. Hal ini membuktikan bahwa guru telah melakukan penguatan kegiatan kepada siswa.

\section{f. Penguatan Mendekati}

Sunarti (2015: 6) menyatakan bahwa penguatan dengan cara mendekati adalah ketika guru mendekati siswa atau kelompok siswa sambil memberikan penguatan yang lain. Berdasarkan penjabaran teori, maka dapat disimpulkan bahwa guru telah melakukan penguatan mendekati kepada siswa. Guru melakukan penguatan mendekati dengan cara mendekati siswa sambil memberikan penguatan gestural saat kegiatan pembelajaran sedang berlangsung. Hal ini guru lakukan saat siswa sedang mengerjakan tugas yang diberikan oleh guru. Selain itu, guru juga melakukan penguatan mendekati ketika siswa sedang mengerjakan tugas secara berkelompok di kelas dengan tujuan agar guru dapat sambil memeriksa pekerjaan yang dilakukan oleh siswa.

\section{Manfaat Keterampilan}

\section{Memberi Penguatan Terhadap Motivasi Siswa}

Penerapan keterampilan dasar mengajar yang guru lakukan saat di kelas, khususnya keterampilan memberi penguatan dapat membuat pembelajaran di kelas lebih menyenangkan. Hal ini tentu saja dapat berdampak terhadap motivasi siswa.Terdapat beberapa indikator motivasi belajar, yaitu adanya hasrat dan keinginan untuk berhasil, adanya dorongan dan kebutuhan dalam belajar, adanya harapan atau cita-cita 
masa depan, adanya penghargaan dalam belajar, adanya kegiatan yang menarik dalam belajar, adanya lingkungan belajar yang kondusif, sebagai berikut :

\section{a. Adanya hasrat dan keinginan untuk berhasil}

Uno (2008: 23) yang menyatakan bahwa jika siswa yang memiliki motif berprestasi, maka siswa akan mengerjakan pekerjaannya secara tuntas tanpa harus menundanunda pekerjaan tesebut. Berdasarkan penjabaran beberapa teori tersebut, maka dapat disimpulkan bahwa guru telah menerapkan berbagai jenis memberi penguatan sehingga siswa memiliki hasrat dan keinginan untuk belajar. Hal ini dapat terlihat dari cara guru dalam mengingatkan secara terus menerus tentang pentingnya belajar sehingga hal tersebut menyebabkan siswa merasa antusias saat kegiatan pembelajaran sedang berlangsung. Hal ini membuktikan bahwa guru telah berhasil mendidik siswa sehingga siswa memiliki hasrat dan keinginan untuk berhasil.

\section{b. Adanya dorongan dan} kebutuhan dalam belajar

Sardiman (2012: 93) yang menyatakan bahwa proses belajar itu akan berjalan lancar jika disertai dengan minat, apabila ada kebutuhan maka motivasi akan muncul. Berdasarkan penjabaran teori tesebut, maka dapat disimpulkan bahwa guru telah menerapkan komponen keterampilan memberi penguatan sehingga siswa memiliki dorongan dan kebutuhan untuk belajar. Guru secara terus menerus memberikan dorongan kepada siswa agar terus belajar. Hal tersebut guru lakukan agar siswa memiliki dorongan dan kebutuhan untuk belajar. Terlihat dari semangat siswa dalam mengikuti proses pembelajaran di dalam kelas merupakan bukti bahwa guru telah berhasil mendidik siswa agar memiliki dorongan dan menjadikan belajar sebagai suatu kebutuhan.

\section{c. Adanya harapan atau cita- cita masa depan}

Budi dalam Hastuti (2016: 47) yang menyatakan bahwa harapan seseorang dapat dipengaruhi oleh perasaannya tentang gambaran dari hasil tindakan yang telah dilakukannya. Sebagai contoh, jika seorang siswa ingin memeroleh hadiah dari guru maka dia harus aktif dan semakin giat dalam kegiatan pembelajaran.

Berdasarkan penjabaran teori tersebut, maka dapat 
disimpulkan bahwa guru telah menerapkan berbagai komponen keterampilan memberi penguatan sehingga siswa memiliki cita-cita atau harapan. Hal tersebut dibuktikan dengan adanya usaha guru dalam mendidik siswa, seperti mengingatkan untuk lebih giat belajar agar siswa mampu mencapai apa yang siswa harapan dan cita-cita untuk masa depan.

\section{d. Adanya penghargaan dalam belajar}

Uno (2008: 23) berpendapat bahwa penghargaan dalam kegiatan belajar merupakan cara yang efektif untuk meningkatkan motivasi siswa agar memeroleh hasil belajar yang lebih baik lagi. Berdasarkan penjabaran teori tersebut, maka dapat disimpulkan bahwa guru telah menerapkan berbagai komponen keterampilan memberi penguatan sehingga siswa memiliki motivasi dalam kegiatan belajar yang diperoleh dari adanya penghargaan dalam kegiatan belajar. Hal ini dibuktikan dengan adanya pemberian hadiah berupa alat tulis oleh guru kepada siswa sehingga siswa semakin termotivasi saat kegiatan pembelajaran sedang berlangsung. Selain itu, guru juga tidak lupa untuk memberikan nilai pada tugas yang telah diselesaikan oleh siswa. Hal tersebut menunjukkan bahwa adanya penghargaan dalam belajar.

\section{e. Adanya kegiatan yang menarik dalam belajar}

Budi dalam Hastuti (2016: 52) yang menyatakan bahwa kegiatan pembelajaran yang menarik dapat menjadikan pembelajaran tersebut lebih bermakna. Pembelajaran bermakna justru dapat menyebabkan siswa selalu mengingat dan memahami pembelajaran tersebut. Berdasarkan penjabaran teori tersebut, maka dapat disimpulkan bahwa kegiatan yang menarik dalam pembelajaran dapat memotivasi siswa. Guru telah mengadakan kegiatan yang menarik dalam pembelajaran, hal ini guru lakukan dengan cara mengajak siswa mengerjakan tugas secara berkelompok yang menyebabkan siswa terlihat antusias saat mengerjakan tugas yang diberikan tersebut.

\section{f. Adanya lingkungan belajar yang kondusif}

Pernyataan tersebut diperkuat dengan pernyataan Fadhilaturrahmi (2018: 62) yang menyatakan bahwa lingkungan belajar merupakan tempat 
terjadinya kegiatan pembelajaran yang dapat mempengaruhi perubahan tingkah laku seseorang. Dalam hal ini, maka sudah seharusnya guru dapat mencipatkan lingkungan belajar yang kondusif bagi siswa. Berdasarkan penjabaran beberapa teori tersebut, maka dapat disimpulkan bahwa guru telah menerapkan keterampilan memberi penguatan sehingga dapat memotivasi siswa saat kegiatan pembelajaran sedang berlangsung. Lokasi sekolah yang berada begitu dekat dengan rumah warga mengakibatkan lingkungan belajar menjadi kurang kondusif. Namun, hal tersebut masih dapat diminimalisir oleh guru sehingga siswa merasa tetap nyaman saat pembelajaran sedang berl berlangsung. Selain itu, cara guru dalam menyampaikan kepada siswa untuk tidak ikut ramai di dalam kelas dengan intonasi suara yang agak nyaring juga membantu sehingga suasana kelas bisa tetap kondusif.

D. Kesimpulan

a. Keterampilan Dasar Mengajar Guru dalam Memberi Penguatan di SDN 011 Tarakan
Terdapat beberapa komponen terkait keterampilan memberi penguatan, yaitu penguatan verbal, penguatan sentuhan, penguatan tanda, penguatan gestural, penguatan mendekati, dan penguatan kegiatan. Adapun kesimpulan yang diperoleh sebagai berikut :

a. Guru memberikan penguatan verbal, berupa kata-kata atau kalimat pujian atas pencapaian yang telah berhasil dilakukan oleh siswa. Adapun penguatan verbal yang guru berikan saat pembelajaran, seperti wow hebat, jawabanmu sudah benar

b. Guru melakukan penguatan tanda yaitu penguatan berupa simbol atau hadiah kepada siswa. Adapun penguatan tanda yang guru berikan adalah guru memberikan hadiah, berupa alat tulis kepada siswa. Selain itu, guru juga memberikan nilai pada tugas-tugas yang telah diselesaikan oleh siswa.

c. Penguatan gestural adalah penguatan berupa gerak tubuh yang guru berikan kepada siswa. Penguatan gestural yang guru lakukan saat pembelajaran sedang berlangsung adalah memberikan senyuman, 
memberikan acungan jempol, dan bertepuk tangan bersama siswa.

d. Guru melakukan penguatan mendekati dengan cara mendekat dengan siswa. Hal tersebut guru lakukan saat siswa sedang mengerjakan tugas, baik secara individu maupun secara berkelompok.

e. Guru melakukan penguatan kegiatan, yaitu penguatan yang guru berikan kepada siswa berupa memberikan kegiatan yang menyenangkan bagi siswa saat pembelajaran sedang berlangsung. Adapun penguatan kegiatan yang guru lakukan saat pembelajaran adalah memberi kegiatan kepada siswa ketika siswa telah menyelesaikan tugas yang diberikan oleh guru. Ketika siswa telah menyelesaikan tugas yang diberikan oleh guru, maka siswa diizinkan istirahat terlebih dahulu.

\section{b. Manfaat Keterampilan}

\section{Memberi Penguatan Terhadap Motivasi Siswa}

Terdapat beberapa indikator motivasi yaitu adanya hasrat dan keinginan untuk berhasil, adanya dorongan dan kebutuhan dalam belajar, adanya harapan atau cita-cita masa depan, adanya penghargaan dalam belajar, adanya kegiatan yang menarik dalam belajar, adanya lingkungan belajar yang kondusif. Adapun kesimpulan yang diperoleh sebagai berikut :

a. Siswa memiliki hasrat dan keinginan untuk berhasil, hal tersebut muncul ketika guru telah menerapkan berbagai macam komponen dari keterampilan dasar memberi penguatan sehingga siswa memilki motivasi dari dalam dirinya sendiri berupa adanya hasrat dan keinginan untuk berhasil.

b. Siswa memiliki dorongan dan kebutuhan untuk belajar, hal tersebut muncul ketika guru telah menerapkan komponen keterampilan memberi penguatan dan guru secara terus menerus memberikan dorongan kepada siswa agar terus belajar. Terlihat dari semangat siswa dalam mengikuti proses pembelajaran di dalam kelas merupakan bukti bahwa guru telah berhasil mendidik siswa agar memiliki dorongan dan menjadikan 
belajar sebagai suatu kebutuhan.

c. Adanya harapan atau cita-cita masa depan, guru telah menerapkan berbagai komponen keterampilan memberi penguatan sehingga siswa memiliki cita-cita atau harapan. Hal tersebutdibuktikan dengan adanya usaha guru dalam mendidik siswa, seperti mengingatkan untuk lebih giat belajar agar siswa mampu mencapai apa yang siswa harapan dan cita-cita untuk masa depan.

d. Siswa memiliki motivasi dalam kegiatan belajar yang diperoleh dari adanya penghargaan dalam kegiatan belajar. Hal ini dibuktikan dengan adanya pemberian hadiah berupa alat tulis oleh guru kepada siswa sehingga siswa semakin termotivasi saat kegiatan pembelajaran sedang berlangsung. Selain itu, guru juga tidak lupa untuk memberikan nilai pada tugas yang telah diselesaikan oleh siswa. Hal tersebut menunjukkan bahwa adanya penghargaan dalam belajar. e. Adanya kegiatan pembelajaran yang menarik yang guru lakukan menyebabkan siswa termotivasi. Guru telah mengadakan kegiatan yang menarik dalam pembelajaran, hal ini guru lakukan dengan cara mengajak siswa mengerjakan tugas secara berkelompok yang menyebabkan siswa terlihat antusias saat mengerjakan tugas yang diberikan tersebut. Siswa dengan berkelompok memberikan semangat satu sama lain

f. Siswa mengharapkan adanya lingkungan belajar yang kondusif, namun pada kenyataannya lokasi sekolah yang begitu berdekatan dengan rumah warga sehingga berdampak padapembelajaran yang menjadi kurang kondusif. Namun, hal tersebut masih dapat diminimalisir oleh guru dengan cara mengingatkan kepada siswa agar tidak ikut ramai saat pembelajaran berlangsung menggunakan intonasi suara yang tinggi.

Berdasarkan kesimpulan yang telah diperoleh peneliti terkait keterampilan dasar mengajar guru 
dalam memberi penguatan di kelas $\mathrm{V}$ SDN 011 Tarakan, peneliti menyampaikan saran sebagai berikut

a. Guru hendaknya terus meningkatkan keterampilan dasar mengajar guru terutama dalam memberikan penguatan sehingga mampu meningkatkan motivasi siswa dalam kegiatan pembelajaran

b. Guru hendaknya memberikan variasi penguatan khususnya untuk penguatan sentuhan, mendekati, dan kegiatan, agar penguatan yang diberikan guru tidak dianggap hal biasa oleh siswa.

c. Pihak sekolah hendaknya dapat meminimalisir dampak dari lingkungan belajar siswa yang kurang kondusif agar siswa dapat semakin nyaman saat kegiatan pembelajaran sedang berlangsung

d. Sebaiknya siswa menghargai usaha guru dalam kegiatan pembelajaran yang sedang berlangsung.

\section{DAFTAR PUSTAKA}

Andini, DM., Supardi, E., (2018). Kompetensi Pedagogik Guru Terhadap Efektivitas Pembelajaran dengan Variabel Kontrol Latar Belakang Pendidikan Guru. Jurnal Pendidikan Manajemen

Perkantoran, (3)1, 151.

Djamarah, Syaiful Bahri. (2000). Guru dan Anak Didik Dalam Interaksi Edukatif. Jakarta: PT Rineka Cipta Fadhilaturrahmi. (2018). Lingkungan Belajar Efektif Bagi Siswa Sekolah Dasar. Jurnal Basiceda, 2(2), 62.

Febianti, YN. (2018). Peningkatan Motivasi Belajar dengan Pemberian Reward and Punishment yang Positif. Jurnal Edunomic, 6(2), 97.

Halimah, Lelli. (2017). Keterampilan Mengajar Sebagai Inspirasi Untuk Menjadi Guru Yang Excellent Di Abad Ke-21. Bandung: PT. Refika Aditama.

Handayani, Hindri. Analisis Motivasi Belajar Terhadap Hasil Belajar Siswa Pada Materi Globalisasi Mata Pelajaran PKN Kelas IV SDN 4 Tapan Tahun Ajaran 2017/2018. Pendas : Jurnal IImiah Pendidikan Dasar, [S.I.], v. 4, n. 2, p. 249 - 258, jan. (2020). ISSN 2548-6950. Available at: $<$ https://journal.unpas.ac.id/index.p $\mathrm{hp} /$ pendas/article/view/1094>.

Date accessed: 08 may 2020. doi: http://dx.doi.org/10.23969/jp.v 4i2.1094

Hastuti, NLD. (2016). Studi Komparasi Motivasi Belajar Biologi Anatar Siswa Kelompok Peminatan dan Kelompok Lintas Minat di SMA Negeri 13 Semarang Tahun Pembelajaran 2016-2017. Skripsi. Semarang: Universitas Islam Negeri Walisongo 
Moleong, JL. (2017). Metodologi Penelitian Kualitatif. Bandung: PT. Remaja Rosdakarya

Sabransyah. (2018). Deskripsi Keterampilan Dasar Guru Dalam Mengelola Kelas Pada Kelas $V$ SDN 007 Tarakan. Skripsi. Tarakan: Universitas Borneo Tarakan

Sardiman, AM. (2014). Interaksi \& Motivasi Belajar Mengajar. Depok: Raja Grafindo Persada.
Yunus, Muhammad; Andari, Kadek Dewi Wahyuni; Addinul Islam, Muhammad. The Principal's Competences In Implementing Cultural And Environmental Management Of The School In Sdn 033 Tarakan. JPI (Jurnal Pendidikan Indonesia), [S.I.], v. 6, n. 2, p. 263-273, oct. 2017. ISSN 2541-7207. Available at: $<$ https://ejournal.undiksha.ac.id/ind ex.php/JPI/article/view/11982/8587 